If the high standard of the first two volumes is maintained in future publications the series will prove a most welcome addition to the libraries of petroleum technologists, but it will only be welcome on these already overburdened shelves if it maintains its selective character and does not become a reference book.

F. MORTON

\section{CHEMICAL AND BIOLOGICAL ACTION OF RADIATIONS}

\section{Radiolyse de Liquides Organiques}

Par Milton Burton. Polymérisations Amorcées par les Radiations lonisantes. Par A. Chapiro et M. Magat. Effets des Rayonnements de Grande Énergie sur les Polymères. Par A. Charlesby. (Actions Chimiques et Biologiques des Radiations, Troisième Série. Collection dirigée par M. Haissinsky.) Pp. iv +222 . (Paris: Masson et Cie., 1958.) Broché, 4,000 franes; cartonné toile, 4,800 franes.

\section{Les Peroxydes Organiques en Radiobiologie}

(Organic Poroxides in Radiobiology). Par R. Latarjet et al. (Actions Chimiques et Biologiques des Radiations, Quatrième Série. Collection dirigée par $\mathbf{M}$. Haissinsky.) Pp. viii + 156. (Paris : Masson et Cie., 1958.) Broché, 2,800 franes; eartonné toile, 3,600 francs.

$\mathrm{T}$ the third volume of Haissinsky's series of monographs the dominant theme, in each of the three topics discussed, is a physicochemical interpretation of the principal radiation effects. The various authors give at the outset a compact account of the theoretical principles which are used in the interpretation, and, in consequence, the articles serve as useful introductions to complex and expanding subjects. A further advantage of the approach is to focus attention on the studies which have led to results of a definitive character. It becomes apparent from the discussions that a great deal of published work in this field is of limited value, due to the fact that inadequate attention has been given to experimental conditions, such as purity of materials, methods of irradiation, and so on.

The theoretical background presented in the article by Burton is to some extent covered by Gray in the first volume of this series, but the reiteration, with greater emphasis on the role of excitation processes, and attention throughout to photochemical analogy, seems appropriate to the purpose in hand. His account of the radiolytic effects includes a range of organic liquids in various chemical classes, although the results obtained with hydrocarbons, which are the most susceptible to interpretation, occupy the major part of the discussion. The other two articles are authoritative and notably lucid. They will no doubt be read by radiobiologists in search of clues, but they also merit the attention of industrial polymer chemists.

The fourth volume is devoted to the proceedings of a colloquium concerned with an evaluation of the concept of organic peroxides as causal agents in radiobiological damage. Sixteen papers are presented, commeneing with a useful account of recent work on the nature of the peroxides resulting from the autoxidation of fats. (The absence of literature references to this paper is an unfortunate omission.) The other topies range from the radiochemical production of peroxides in in vitro systems (cumene, polystyrene, nucleic acids), to the biological effects of peroxides, and the influence of oxygen on radiation effects produced in a number of biological systems. The discussions on the individual papers, and a valuable discussion on the main theme of the colloquium, are freely recorded in this volume.

The high standards set in the first two volumes of this series are well maintained in the present additions. W. ANDERSON

\section{SCIENTIFIC MEDICINE FOR POSTGRADUATES}

\section{Lectures on the Scientific Basis of Medicine}

Vol. 7, 1957-58. (British Postgraduate Medical Federation: University of London.) Pp. xii $+496+$ 33 plates. (London: The Athlone Press, University of London, 1959.) Distributed by Constable and Co., Ltd. 45s. net.

JNTIL a relatively short time ago, experience was the great postgraduate teacher, but the progress of knowledge in the past thirty years has made it clear that experience alone is no longer enough. Other teachers are necessary, capable of helping medical men and women to implement the new ideas and discoveries in their daily work whatever that may be. Twenty-three of these teachers have prepared their lectures for this book. It is the seventh in a well-known series, and the subjects covered are as wide as before. They range from studies of the growth of viruses to biochemical deficiencies in the whole animal, and include lectures on hæmatology, biochemical genetics, cell regeneration, pharmacology, minutiæ of the eye and ear, the stability of collagen and ageing processes in the female reproductive tract.

The subjects could only have been presented by an equal number of specialists, and they display the complexity of the biological framework as it is gradually becoming revealed to us. No one man can comprehend more than a fraction of it all in detail, but these lectures year by year are mostly simple enough to allow the interested reader to draw his own conclusions as to the bearing, if any, they may have on his daily round. Nevertheless, the spoken word is often easier to follow than the written one, and some of these lectures must be studied with care to get the most out of them, and for many people time and interest will be the limiting factors.

This series of books is described as a venture in postgraduate education, intended for graduates in medicine looking forward to careors as teachers and consultants in medicine and surgery and their special branches, as well as for those seeking careers in research and teaching in the medical sciences. This is a very fair appraisal and the sponsors may congratulate themselves on their venture. It is only one of the many now being made in postgraduate education. The short courses lasting from one to three days now being held at the Royal College of Physicians, at Cambridge and in many other parts of Britain, have rather a different appeal, but judging by thoir success, whether the proceedings are pub. lished afterwards or not, there is evidently a widespread demand for knowledge among specialists and practitioners, and an appreciation of the efforts which ure being made to provide it for them.

R. A. MOCANCE 